\title{
Investigation of the Frictionless Contact Problem in A Rigidly Supported Homogeneous Layer by Using FEM
}

\author{
Rijit Olarak Mesnetlenmiş Homojen Tabakada Sürtünmesiz Temas Probleminin Sonlu \\ Elemanlar Metodu ile İncelenmesi
}

\author{
Alper POLAT* \\ Munzur University, Faculty of Engineering, Civil Engineering Department, 62000, Tunceli \\ • Geliş tarihi / Received: 22.05.2019 • Düzeltilerek geliş tarihi / Received in revised form: 07.08.2019 • Kabul tarihi / Accepted: 09.09.2019
}

\begin{abstract}
In this study, the continuous contact problem of a homogeneous layer of constant thickness perfectly bonded to a rigid support on its bottom surface and loaded a rigid stamp is investigated using the finite element method (FEM). It is assumed that the all contact surfaces are frictionless. The homogenous layer is loaded by rigid circular stamp with external load P. Two-dimensional finite element analysis of the problem is performed using ANSYS software. Also, normal stresses and shear stresses are investigated along the depth of the layer for different shear modulus ratios. Besides, contact length and contact stress between rigid block and homogenous layer are determined. The obtained results are compared to analytical solution and they are shown in graphs and tables.
\end{abstract}

Anahtar kelimeler: Contact problem, Finite element method, Homogenous layer, Rigid stamp

$\ddot{O} z$

Bu çalışmada, alt yüzeyinden rijit olarak mesnetlenmiş ve rijit bir dairesel blok ile yüklenmiş sabit yükseklikli bir homojen tabakada sürekli temas problemi sonlu elemanlar yöntemi kullanllarak incelenmişstir. Bütün yüzeylerin sürtünmesiz olduğu kabul edilmiştir. Homojen tabaka, dış yükü P olan bir rijit dairesel blok vasıtaslyla yüklenmiştir. Problemin iki boyutlu sonlu elemanlar analizi ANSYS yazllmı kullanılarak gerçekleştirilmiştir. Ayrıca farkl yükleme durumlar için tabakanın derinliği boyunca normal gerilmeler ve kayma gerilmeleri incelenmişstir. Bunun yanı sıra rijit blok ile homojen tabaka arasindaki temas mesafeleri ve temas gerilmeleri belirlenmiştir. Elde edilen sonuçlar analitik sonuçlarla kiyaslanarak grafik ve tablo halinde gösterilmiştir.

Keywords: Temas problemi, Sonlu elemanlar yöntemi, Homojen tabaka, Rijit zımba

*Alper POLAT; apolat80@gmail.com; Tel: (+90507) 259 69 68; orcid.org/ 0000-0002-6368-5276 


\section{Introduction}

Contact problems have found wide application areas in several engineering structures such as foundations, fuel oil tanks, airport runways, spherical balls. The subject of contact mechanics, came up in 1882 with an article titled, 'Contact of Elastic Layers' which was discussed by Hertz firstly. Many researchers have discussed the problems analytically such as crack problems, continuous and discontinuous contact, receding contact, and frictional contact until today. (Adiyaman et al. 2016) investigated the contact problem of elastic layer resting on two elastic quarter planes. The layer was loaded by rigid cylindrical stamp. (Ratwani and Erdoğan, 1973) examined the frictionless contact problem of the layer loaded with a rigid or elastic punch, resting on an elastic half-plane. (Civelek and Erdoğan, 1974) solved the axisymmetrical double contact problem for a frictionless elastic layer. (Giannakopoulos and Pallot, 2000) analyzed the frictionless contact problem for an elastic layer which was loaded through a rigid cylindrical block and lying on elastic half-plane. (Çömez, 2010), (Özşahin et al. 2007), (Bora, 2016) and (Polat et al. 2018) investigated continuous and discontinuous contact problems in the elastic layer loaded by rigid block. (Çömez, 2015) examined the frictional contact problem in a functionally graded layer loaded with a moving rigid cyclical block. (Elhaskawy, 1999) analyzed the stress distributions for different friction parameters when the half-plane covered by the two elastic layers was loaded with a rigid curvilinear punch.

The development of numerical calculation methods that produce approximate solutions with the help of computer programs, facilitates the solution of long-term engineering problems of the analytical solution. One of these methods is the Finite Element Method. Firstly, this method is developed a solution to the plane contact problem of elastic bodies by (Chan and Tuba, 1971).
(Bussetta et al. 2012), (Franke et al. 2010), (Birinci et al. 2015), (Kaya et al. 2018) discussed the comparison of contact algorithms in finite element analysis of contact problems. (Nikbakht et al. 2013) examined the frictionless elastic contact of a functionally graded vitrified low carbon steel plate and a rigid spherical punch. (Öner et al. 2015) investigated the continuous and discontinuous contact problem of layer under the pressure influence by using FEM. (Abhilash and Murty, 2014) considered indenters of different typical surface profiles and the problem is idealized as a two-dimensional plane strain problem considering only normal loads.

In this paper, frictionless and continuous contact problem is solved in an elastic layer which is rigidly supported by the top surface and loaded with rigid circular block by using FEM. Using the FEM, the continuous contact problem is solved for different shear modulus $(\mu)$ and different values of a material constant $(\kappa)$. The contact distances and contact stresses between the rigid block and the elastic layer determined by using FEM are compared with (Kahya, 1997). As a finite element model is created, the layer is supported from the top surface and loaded from the upper surface by the rigid block, unlike the analytical solution. Since the mass forces are not considered, this is not affected to comparison with the analytical results.

\section{Definition of The Problem}

In this study, the frictionless contact problem between a rigid block and elastic layer supported by the top is solved by using the FEM. The concentrated load is transferred to the layer by means of a rigid block. All sur-faces are considered to be frictionless. In addition, mass forces are neglected to solutions. The homogeneous layer extends between $(-\infty,+\infty)$. In addition, the rigid block is in contact with the homogeneous layer in the range $(-\mathrm{c},+\mathrm{c})$.

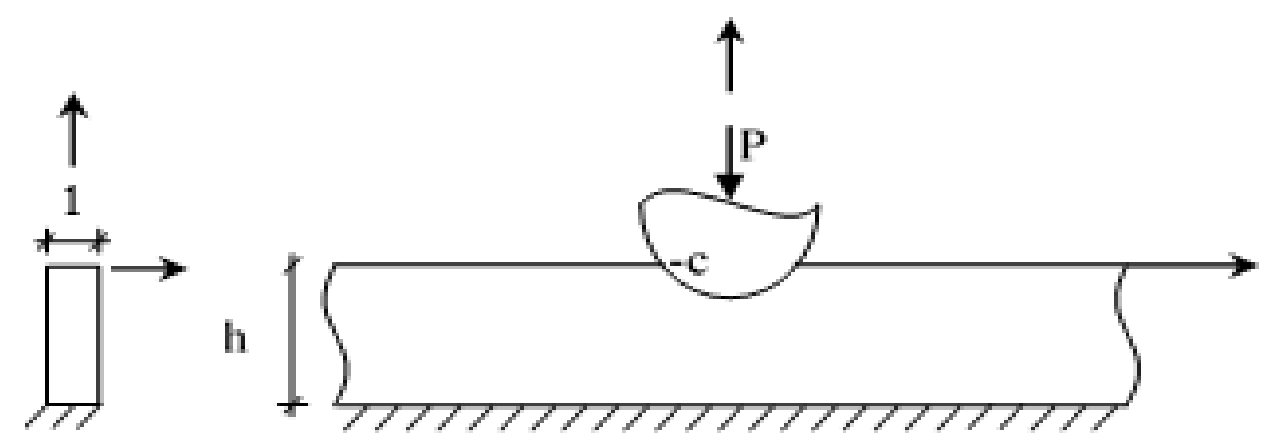

Figure 1. Geometry of the problem 
Analytical solution of the problem is obtained using theory of elasticity and integral transform techniques. Equilibrium equations are written as follows:

$$
\begin{aligned}
& \frac{\partial \sigma_{x}}{\partial x}+\frac{\partial \tau_{x y}}{\partial y}=0 \\
& \frac{\partial \tau_{y x}}{\partial x}+\frac{\partial \sigma_{y}}{\partial y}=0
\end{aligned}
$$

Stress-strain expressions can be written as;

$$
\begin{aligned}
& \sigma_{x}=\lambda e+2 \mu\left(\frac{\partial u}{\partial x}\right) \\
& \sigma_{y}=\lambda e+2 \mu\left(\frac{\partial v}{\partial y}\right) \\
& \tau_{x y}=\mu\left(\frac{\partial u}{\partial y}+\frac{\partial v}{\partial x}\right) \\
& e=\left(\frac{\partial u_{2}}{\partial x}+\frac{\partial v_{2}}{\partial y}\right) \\
& \lambda=\left(\frac{E v}{(1+v)(1-2 v)}\right) \\
& \mu=\left(\frac{E}{2(1+v)}\right) \\
& u(x, y)=\frac{2}{\pi} \int_{0}^{+\infty} \phi(\alpha, y) \operatorname{Sin}(\alpha x) d \alpha \\
& v(x, y)=\frac{2}{\pi} \int_{0}^{+\infty} \psi(\alpha, y) \operatorname{Cos}(\alpha x) d \alpha
\end{aligned}
$$

Expressions are given in these equations;

$\mu, \lambda$ are Lamé Constant, $\mathrm{E}$ is Young Modulus and $v$ is Poisson's Ratio. $\mathrm{u}(\mathrm{x}, \mathrm{y})$ and $\mathrm{v}(\mathrm{x}, \mathrm{y})$ and $\mathrm{x}-$ component and $\mathrm{y}$-component of the displacement vector. The layer is assumed isotropic and elastic. In the analyzes, geometry and material properties are taken as length of the layer in $\mathrm{x}$ direction $(\mathrm{L}=2 \mathrm{~m}$.), layer height $(\mathrm{h}=10 \mathrm{~cm}$.), Young Modulus $(\mathrm{E}=50000 \mathrm{MPa})$, Poisson's Ratio $(v=0.20)$.

\section{Solution with Finite Element Method}

Finite element method (FEM) is a numerical method used to obtain approximate solution which reducing complex problems to simple subproblems. The basic principle of the FEM is to subtract the equations containing the system properties of an element and to combine the element equations to represent the whole system and thus to obtain the linear equation set for the system. In this work, the finite element model and solution of the problem is carried out by using ANSYS (2016) package program. When modeling, the mass forces and the friction force under rigid block are neglected. Linear, elastic and isotropic materials are used in all parts of the model. Determining the element type is important in terms of getting correct results for solving the problem. Since this study is a static and 2dimensional plane problem, PLANE183 with 8 nodes is used as the element type. In modeling, the surface-surface contact model is used because of the fact that they provided solutions even if the nodes are not overlapped. When the contact pair is formed, the target surface is defined by the TARGE169 element and the contact surface by the CONTA172 element. For surfaces in contact with each other, the surface having a modulus of elasticity is selected as the target. The elements of the TARGE169 and CONTA172 are elements comprising three nodes, these nodes overlapping the nodes on the surface of the PLANE183 element. In mesh process, all lines of the geometry are divided into 0.05 mesh spacing. Also all lines are divided to more smaller parts but the results did not changed and solution time increased. In the solution are used 91200 nodes and 46500 elements. Additionally, all geometry are meshed with free triangular meshing. ANSYS has various contact algorithms depending on the problem type. In this study, Augmented Lagrangian Method is preferred, which uses the total potential energy theorem as the contact algorithm and gives better and faster results than other algorithms. The ANSYS model of the problem is shown in Figure 2, and the FEM algorithm for solving the problem is shown in Figure 3:

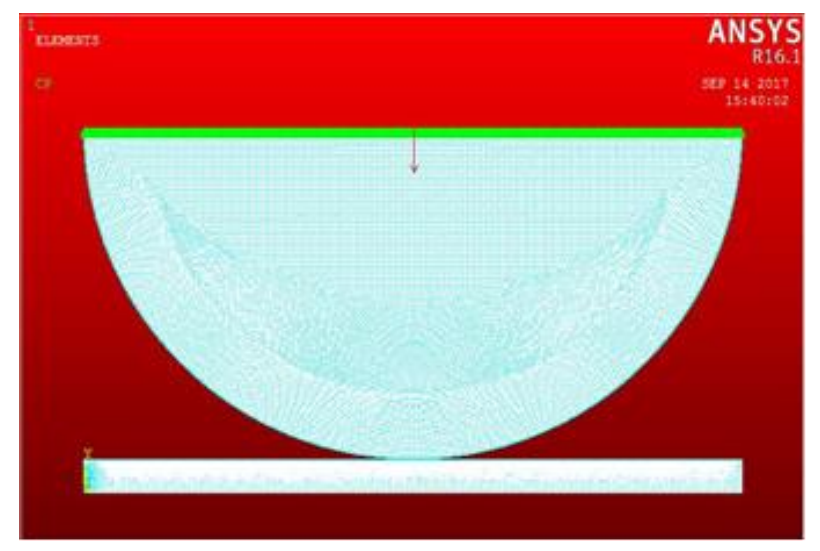

Figure 2. Finite element model of the problem 


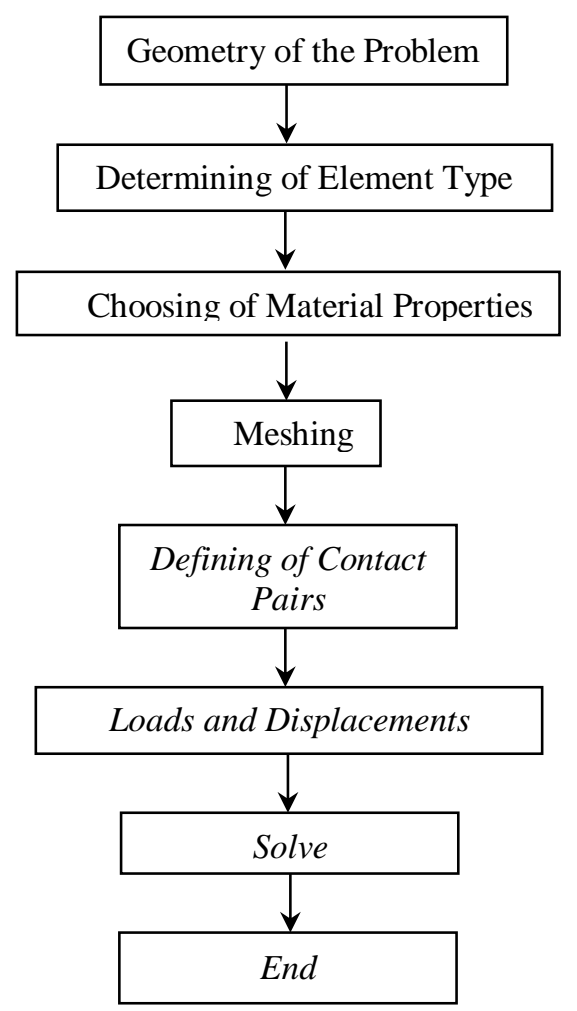

Figure 3. FEM algorithm of the problem

\section{Results and Discussions}

In this study, FEM analysis of a continuous contact problem is carried out. The thickness of the layer and the load are considered as constant, the results obtained by using the FEM of continuous contact problems, for different shear modulus and different Kolosov's constants, are presented in Figures 4-6 and Tables 1-2. The Kolosov's constant $(\kappa)$ is a material constant based on the Poisson's ratio, which decreases as the Poisson's ratio increases. The increase of the Poisson's ratio means that the material is more rigid. As a result of the study, contact distances between the rigid block and the elastic layer are determined by using the FEM and compared with the analytical solution by (Kahya, 1997).

Figure 4 shows the contact stress distributions for different load factors. In the figure, the contact stresses under the rigid block are defined as dimensionless quantities depending on the shear modulus change. While the contact stresses are the largest value on $\mathrm{x}=0$, they are zero at the point where the contact ends.

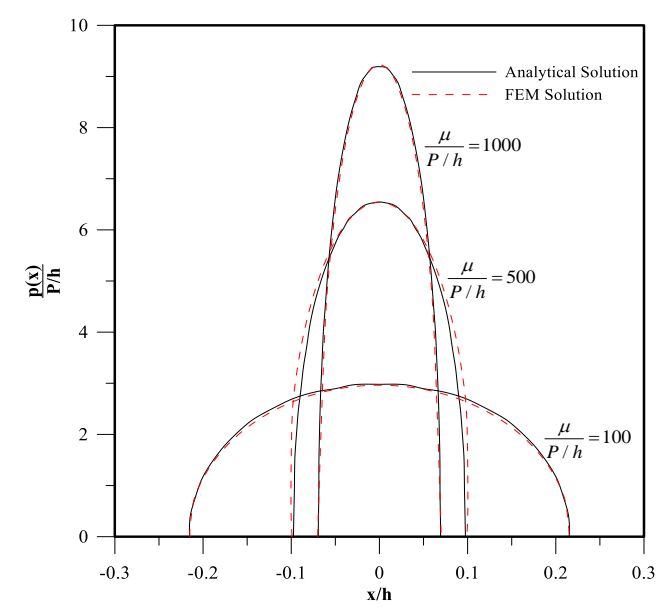

Figure 4. Distribution of contact stress for various shear modulus values $(R / h=10, \kappa=2)$

Table 1 shows the change of the contact area depending on Kolosov's constant. As the Kolosov's constant increases, the contact surface grows too.

Table 1. Change of contact surface depending on Kolosov's constant $\left(R / h=10, \frac{\mu}{P / h}=100\right)$

\begin{tabular}{cccc}
\hline & & $\mathrm{c} / \mathrm{h}$ & Error $(\%)$ \\
\hline$\kappa=1.5$ & Analytical Solution & FEM Solution & 0.76 \\
$\kappa=2$ & 0.196497 & 0.195 & 2.41 \\
$\kappa=2.5$ & 0.215190 & 0.210 & 0.97 \\
\hline
\end{tabular}

Table 2. Change of contact surface depending on shear modulus $(\kappa=2, R / h=10)$

\begin{tabular}{cccc}
\hline$\mu$ & & $\mathrm{c} / \mathrm{h}$ & Error $(\%)$ \\
\hline$P / h$ & Analytical Solution & FEM Solution & 2.41 \\
200 & 0.215190 & 0.21 & 2.15 \\
300 & 0.153296 & 0.15 & 4.37 \\
400 & 0.125488 & 0.12 & 1.08 \\
500 & 0.108818 & 0.11 & 2.66 \\
600 & 0.097407 & 0.10 & 1.16 \\
700 & 0.088967 & 0.09 & 2.91 \\
800 & 0.082399 & 0.08 & 2.72 \\
900 & 0.077099 & 0.075 & 3.72 \\
1000 & 0.072706 & 0.07 & 1.46 \\
\hline
\end{tabular}


In Table 2, the contact distances for the various shear modulus obtained by the analytically and FEM are given comparatively. As the shear modulus values increase, the contact surface becomes smaller.

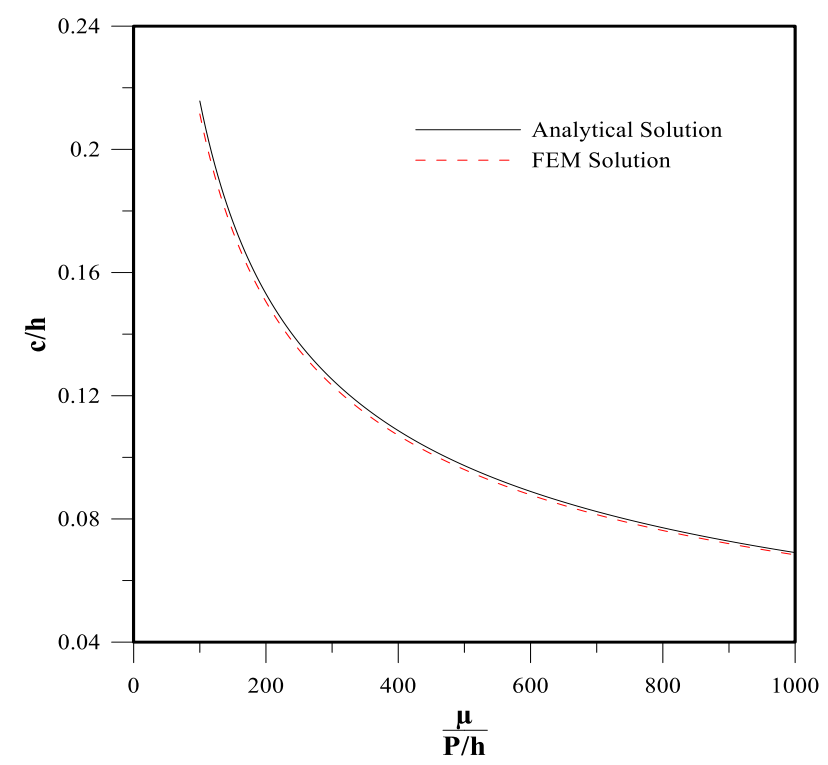

Figure 5. Change of contact surface depending on load factor $(R / h=10, \kappa=2)$

In Figure 5, when the block radius $(R / h)$ is 10 units, the change of the contact surface with the shear modulus is compared with the analytical method and the FEM. There, increase of $\mu / P / h$ ratio which is a dimensionless quantity, means the increase of the shear modulus if the load and height are constant. When Figure 4-5 and Table 12 are examined, it is seen that the solution obtained by the FEM is very compatible with the analytical solution and the contact distance decreases as the shear modulus increasing. Figure 6 shows the analysis of the stress in relation to the dimensionless load factor change along the depth of the homogeneous layer. When the figure is examined, stress values of the under the rigid block increased as the shear modulus values increased. Figure $7(\mathrm{a}-\mathrm{c})$ shows the along the depth of the layer dimensionless $\sigma_{x}(0, y)$ stress distribution obtained from the ANSYS solution. In this analysis, when the shear modulus increases along the depth of the layer, it is observed that the $\sigma_{x}(0, y)$ stress values on the top surface of the layer increased. The graphs are consistent with Figure 6.

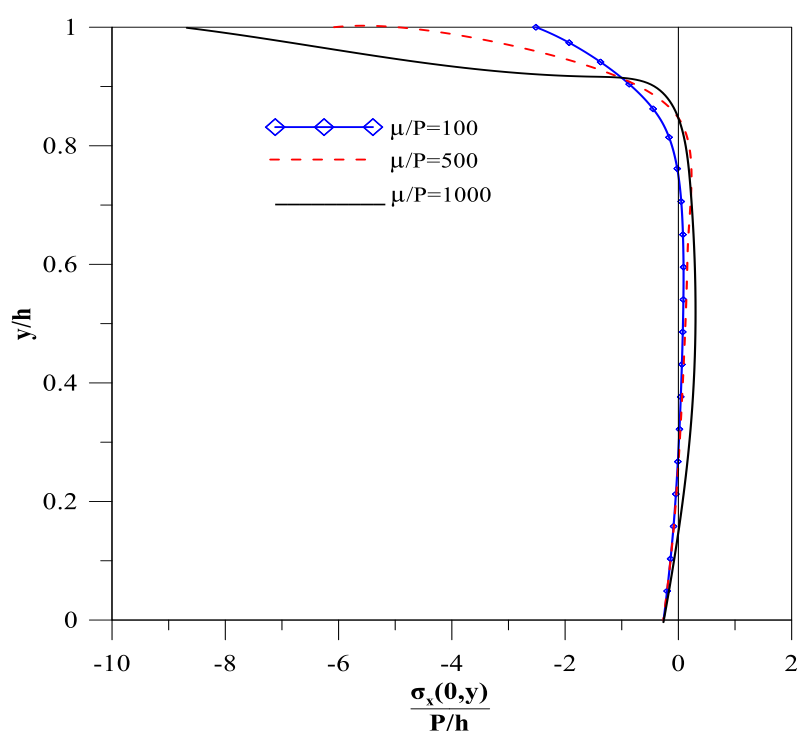

Figure 6. Analysis of $\sigma_{x}(0, y) / P / h$ stress in relation to the dimensionless load factor $\mu / P / h$ change along the depth of the homogeneous layer 


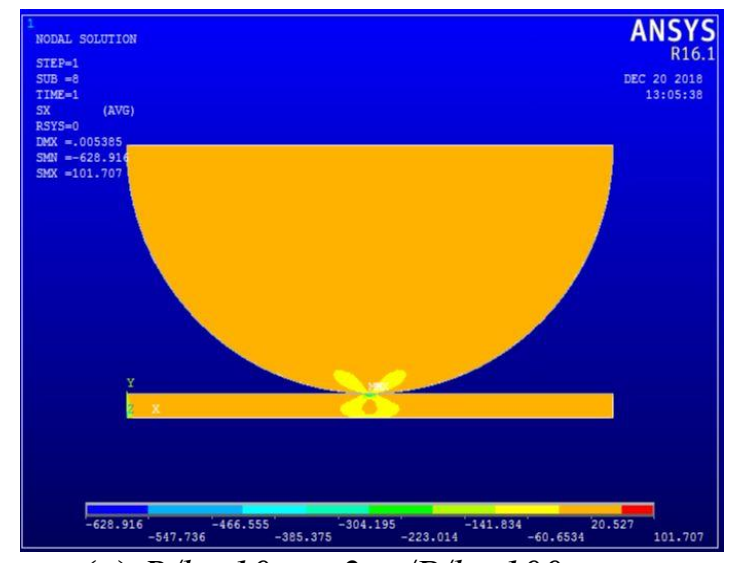

(a) $R / h=10, \kappa=2, \mu / P / h=100$

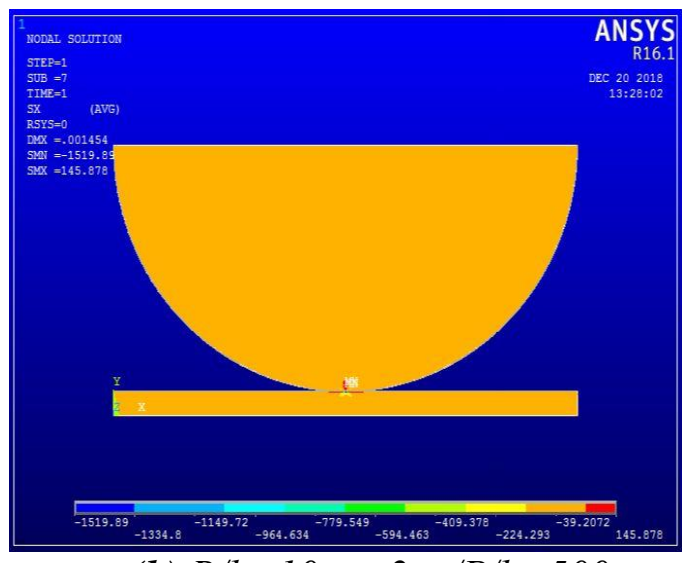

(b) $R / h=10, \kappa=2, \mu / P / h=500$

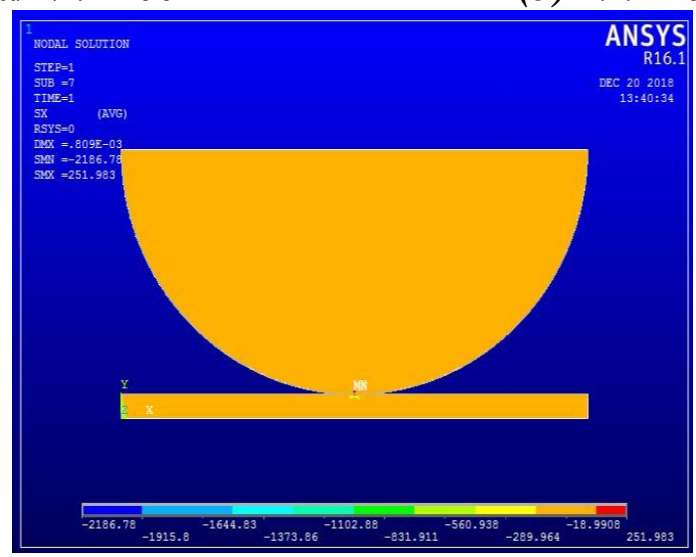

(c) $R / h=10, \kappa=2, \mu / P / h=1000$

Figure 7 (a-c). $\sigma_{x}(0, y) / P / h$ stress distributions obtained by the FEM, depending on the change of the shear modulus

Figure 8 shows the analysis of the $\sigma_{y}(0, y) / P / h$ stress in relation to the shear modulus variation along the depth of the homogeneous layer. As the shear modulus values increased, the $\sigma_{y}(0, y) / P / h$ stress values increased under the rigid block. Figure $9(\mathrm{a}-\mathrm{c})$ shows the dimensionless $\sigma_{y}(0, y) / P / h$ stress distribution obtained from the ANSYS solution. It is observed that as the shear modulus increases, the stress extends to a larger area in both the rigid block and the homogeneous layer.

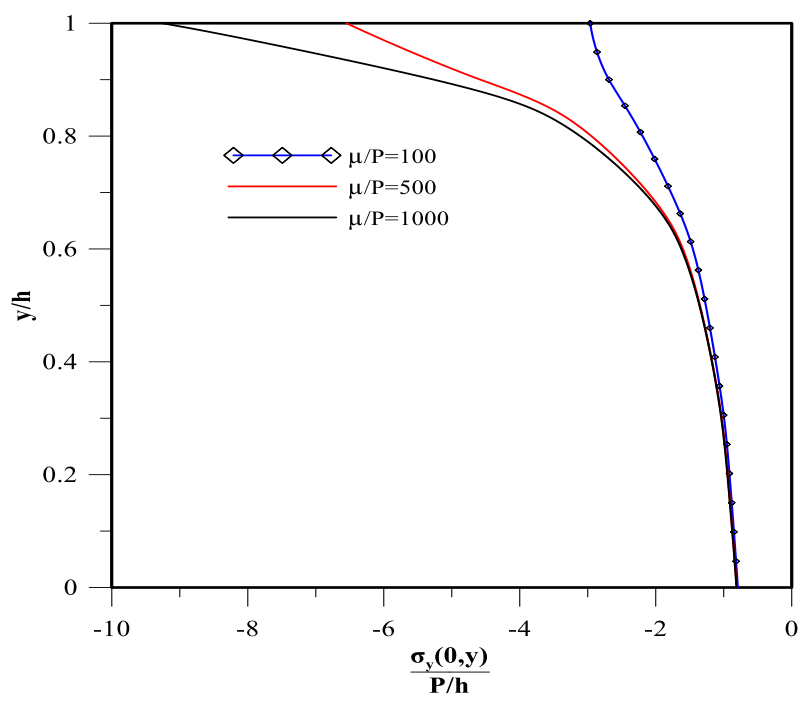

Figure 8. Analysis of the $\sigma_{y}(0, y) / P / h$ stress according to the variation of dimensionless load factor $\mu / P / h$ along the depth of the homogeneous layer 


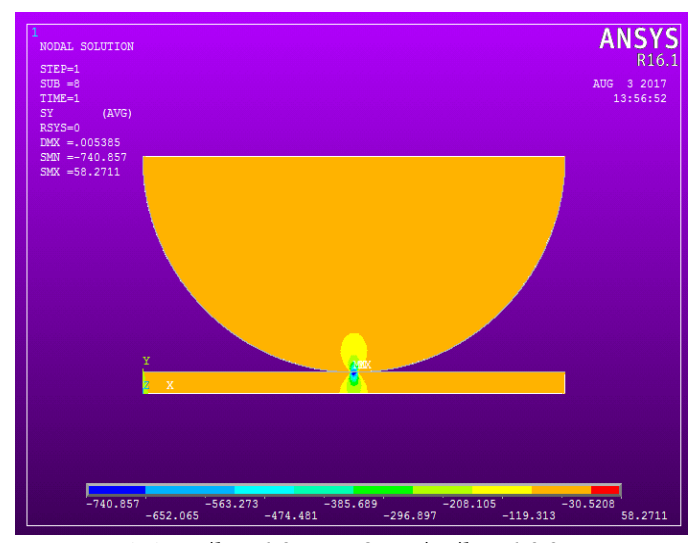

(a) $R / h=10, \kappa=2, \mu / P / h=100$

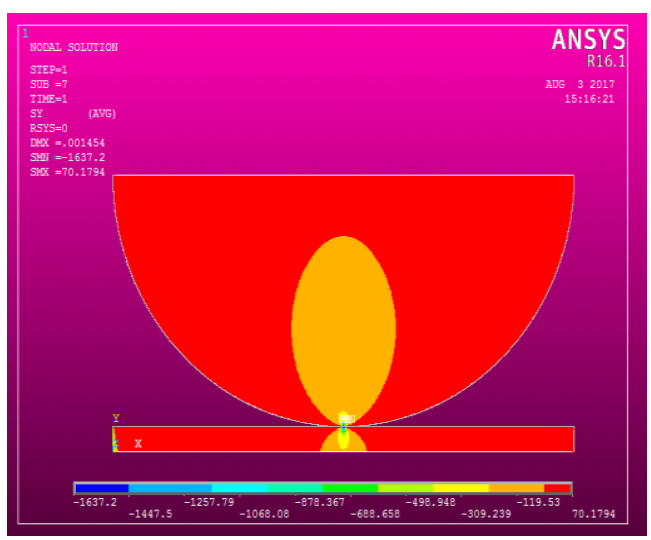

(b) $R / h=10, \kappa=2, \mu / P / h=500$

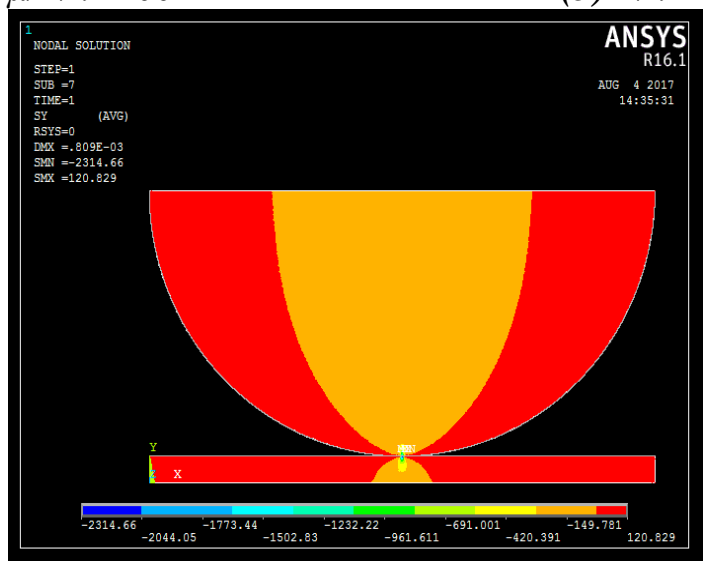

(c) $R / h=10, \kappa=2, \mu / P / h=1000$

Figure 9 (a-c). $\sigma_{y}(0, y) / P / h$ stress distributions obtained by the FEM, depending on the change of the shear modulus

Figure (10-11) shows the analysis of the shear stress of $\tau_{x y}(1, y) / P / h$ and $\tau_{x y}(4, y) / P / h$ according to the shear modulus variation along the depth of the homogeneous layer. When the shape is examined, it is observed that the increase in shear modulus values had little effect on the change of shear stress distributions. In Figure 12 (a-c), the dimensionless $\tau_{x y} / P / h$ stress distribution obtained from ANSYS solution is given. It is observed that as the shear modulus increases, the stress extends to a larger area in both the rigid block and the homogeneous layer.

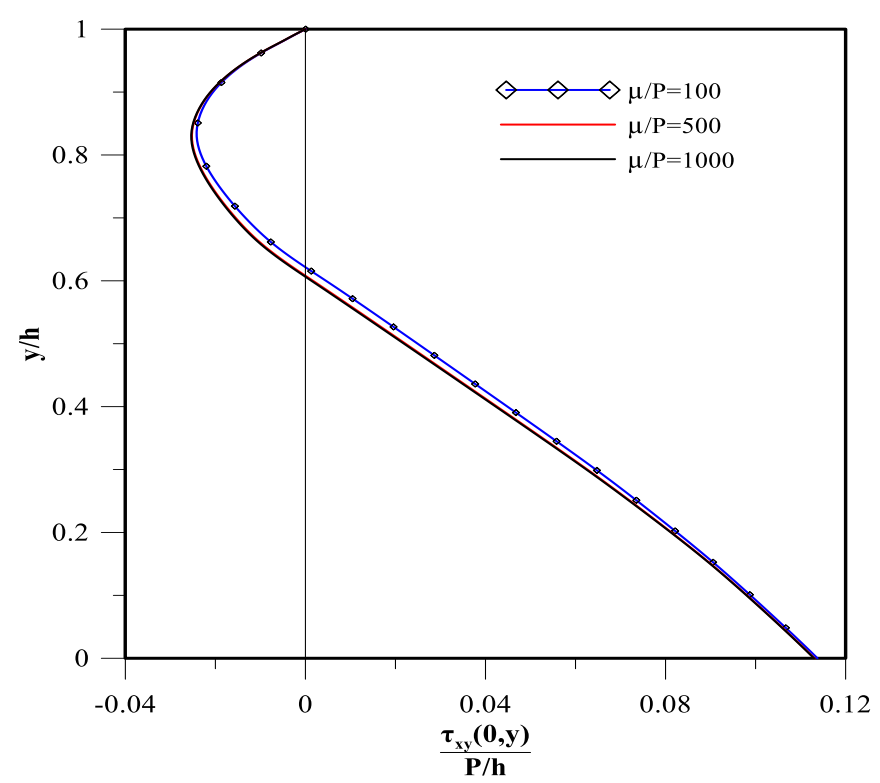

Figure 10. Analysis of the $\tau_{x y}(1, y) / P / h$ shear stress over the depth of the homogeneous layer vesus the dimensionless load factor $(\mu / P)$ 


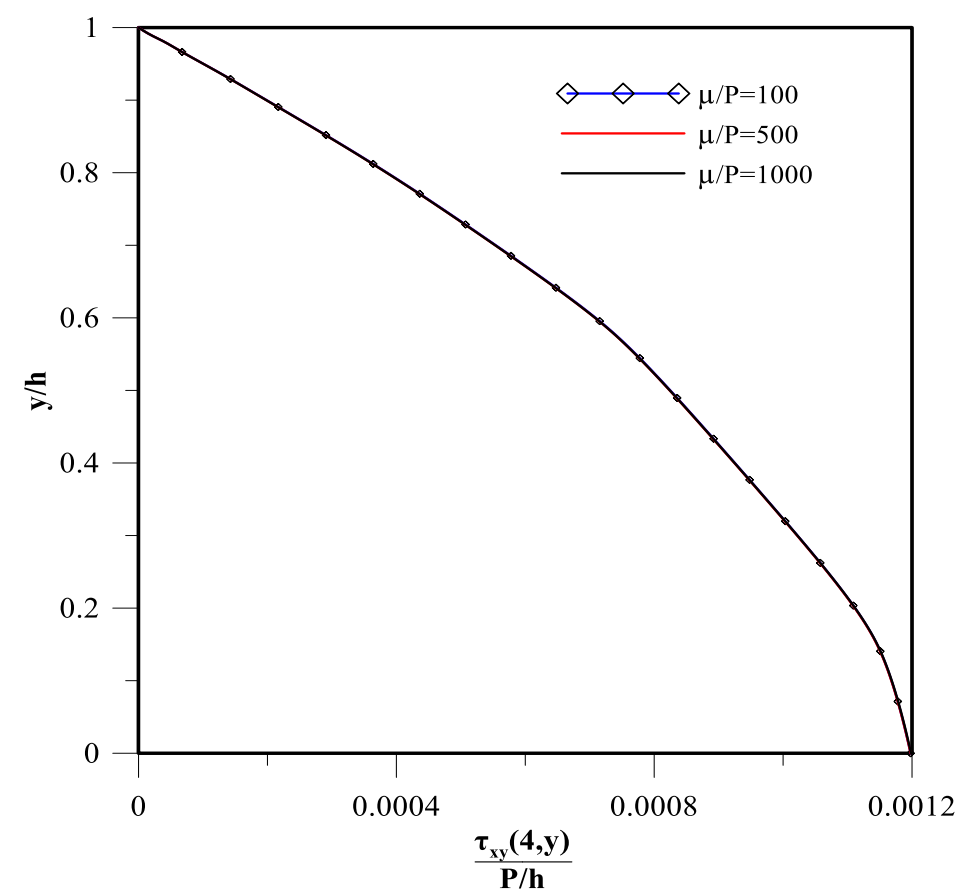

Figure 11. Analysis of the $\tau_{x y}(4, y) / P / h$ shear stress over the depth of the homogeneous layer versus the dimensionless load factor $(\mu / P)$

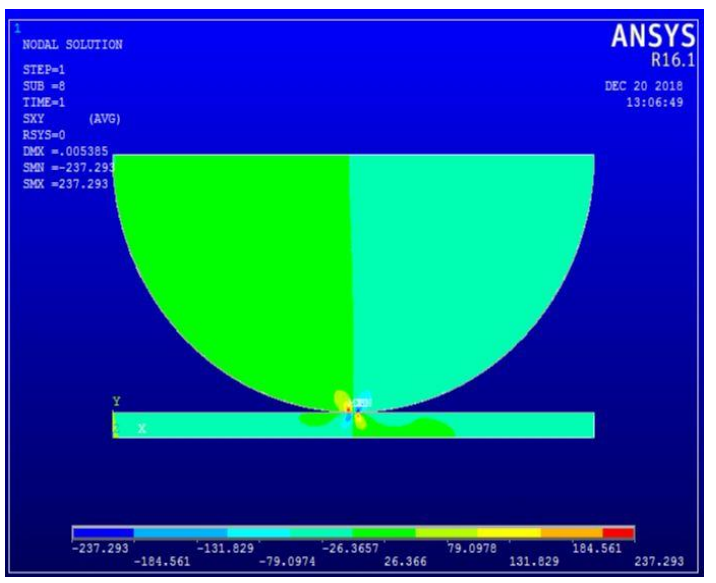

(a) $R / h=10, \kappa=2, \mu / P / h=100$

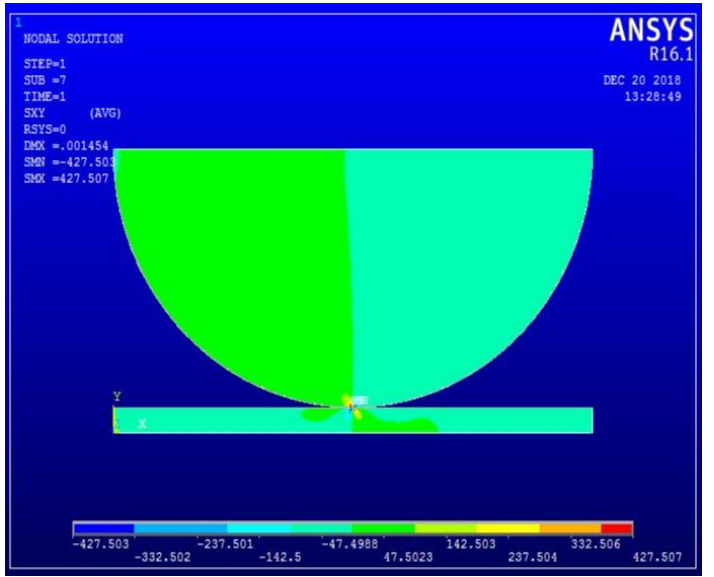

(b) $R / h=10, \kappa=2, \mu / P / h=500$

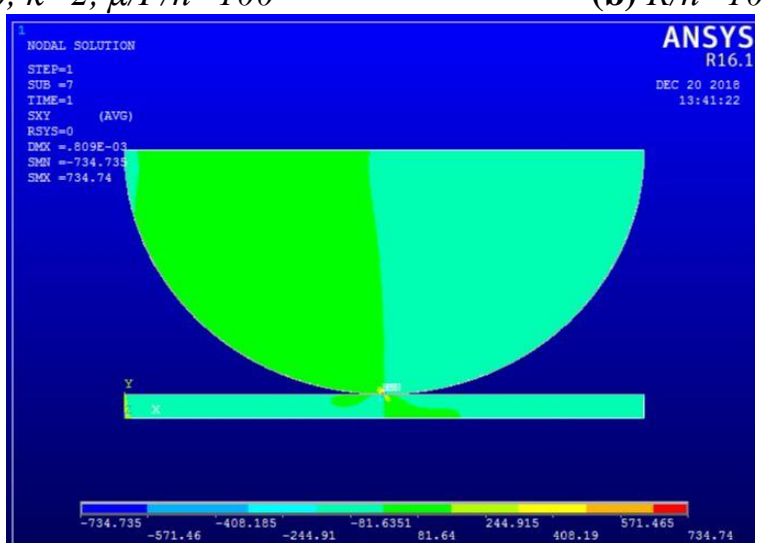

(c) $R / h=10, \kappa=2, \mu / P / h=1000$

Figure 12 (a-c). $\tau_{x y}(0, y) / P / h$ shear stress distributions obtained by the FEM depending on the change of the shear modulus 


\section{Conclusions}

In this paper, the frictionless contact problem between a rigid block and elastic layer supported by the top is solved by using the FEM. The finite element model of the study is performed by using the ANSYS program. The results are compared with the analytical solution according to the change of shear modulus and the Kolosov's constant. It is seen that the results are quite compatible with each other. Also, the results of analyzes that are not performed with analytical solution can be seen in a short time with this software. According to this, stress analysis along the depth of the layer, which is also not an analytical solution, is presented in this study. As the shear modulus increased along the depth of the layer, $\sigma_{x}$ and $\sigma_{y}$ normal stress values under the rigid block increased.but the shear stress values $\tau_{x y}$ did not change too much.

\section{References}

Abhilash M. N. ve Murthy H., 2014. Finite Element Analysis of 2D Elastic Contacts Involving FGMs, International Journal for Computational Methods in Engineering Science and Mechanics, 15, 253-257

Adiyaman, G., Oner E., Yaylaci M. ve Birinci, A., 2016. A Receding Contact Problem between A Functionally Graded Layer and Two Homogeneous Quarter Planes, Acta Mechanica, 227, 1753-1766

ANSYS, 2016, Swanson Analysis Systems Inc., Houston PA, USA.

Birinci A., Adiyaman G., Yaylaci M. ve Öner, E., 2015. Analysis of Continuous and Discontinuous Cases of A Contact Problem Using Analytical Method and FEM, Latin American Journal of Solids and Structures, 12, 1771-1789

Bora P., 2016. İki Rijit Dikdörtgen Blok Ile Yüklenmiş Elastik Yarı Sonsuz Düzlem Üzerine Oturan Iki Elastik Tabakanın Temas Problemi, Ph.D. Thesis, Karadeniz Technical University, Trabzon, Turkey

Bussetta A., Marceau D. ve Ponthot J.P., 2012. The Adapted Augmented Lagrangian Method: A New Method for Resolution of The Mechanical Frictional Contact Problem, Computational Mechanics, 49(2), 259-275

Chan S.K. ve Tuba I.S., 1971. A Finite Element Method for Contact Problems of Solid BodiesPart I. Theory and Validation, International Journal of Mechanical Sciences, 13, 615-625
Civelek M.B. ve Erdoğan F., 1974. The Axisymmetrical Double Contact Problem for A Frictionless Elastic Layer, International Journal of Solids and Structures, 10(6), 639-659

Çömez İ., 2010. Frictional Contact Problem for A Rigid Cylindrical Stamp and An Elastic Layer Resting on A Half Plane, International Journal of Solids and Structures, 47(7-8), 1090-1097.

Çömez İ., 2015. Contact Problem for A Functionally Graded Layer Indented by A Moving Punch, International Journal of Mechanical Sciences, 100, 339-344

Elhaskawy A. A., 1999. Effect of Friction on Subsurface Stresses in Sliding Line Contact of Multilayered Elastic Solids, International Journal of Solid and Structures, 36, 2903-3915

Franke D., Düster A., Nübel V. ve Rank E., 2010. A comparison of The H-, P-, Hp- and Rp Version of The FEM for The Solution of The 2D Hertzian Contact Problem, Computational Mechanics, 45,513-522

Giannakopoulos A.E. ve Pallot P., 2000. TwoDimensional Contact Analysis of Elastic Graded Materials, Journal of The Mechanics and Physics of Solids, 48,1597-1631

Kahya V., 1997. Üst Tarafindan Rijit Olarak Mesnetlenmiş Elastik Bir Tabaka İle Rijit Bir Blok Arasındaki Sürtünmesiz Değme Problem, Master Thesis, Karadeniz Technical University, Trabzon, Turkey

Kaya Y., Polat A. ve Özsahin T.Ş., 2018. Comparison of FEM Solution with Analytical Solution of Continuous and Discontinuous Contact Problem, Sigma Journal of Engineering and Natural Sciences, 36(4), 977-992

Nikbakht A., Arezoodar A.F., Sadighi M., Zucchelli A. ve Lari A.F., 2013. Frictionless Elastic Contact Analysis of A Functionally Graded Vitreous Enameled Low Carbon Steel Plate and A Rigid Spherical Indenter, Composite Structures, 96,484-501

Öner E., Yaylacı M. ve Birinci A., 2015. Analytical Solution of A Contact Problem and Comparison with The Results from FEM, Structural Engineering and Mechanics, 54(4), 607-622

Özşahin T.Ş., Kahya, V. ve Çakıroğlu A., O. 2007. Contact Problem for An Elastic Layered Composite Resting on Rigid Flat Supports, International Journal of Computational and Mathematical Sciences, 1(2), 145-159

Polat A., Kaya Y. ve Özsahin T.Ş., 2018. Analytical Solution to Continuous Contact Problem for A Functionally Graded Layer Loaded Through 
Two Dissimilar Rigid Punches, Meccanica, 53(14), 3565-3577

Ratwani M. ve Erdoğan F., 1973. On The Plane Contact Problem for A Frictionless Elastic
Layer, International Journal of Solids and Structures, 9, 921-936

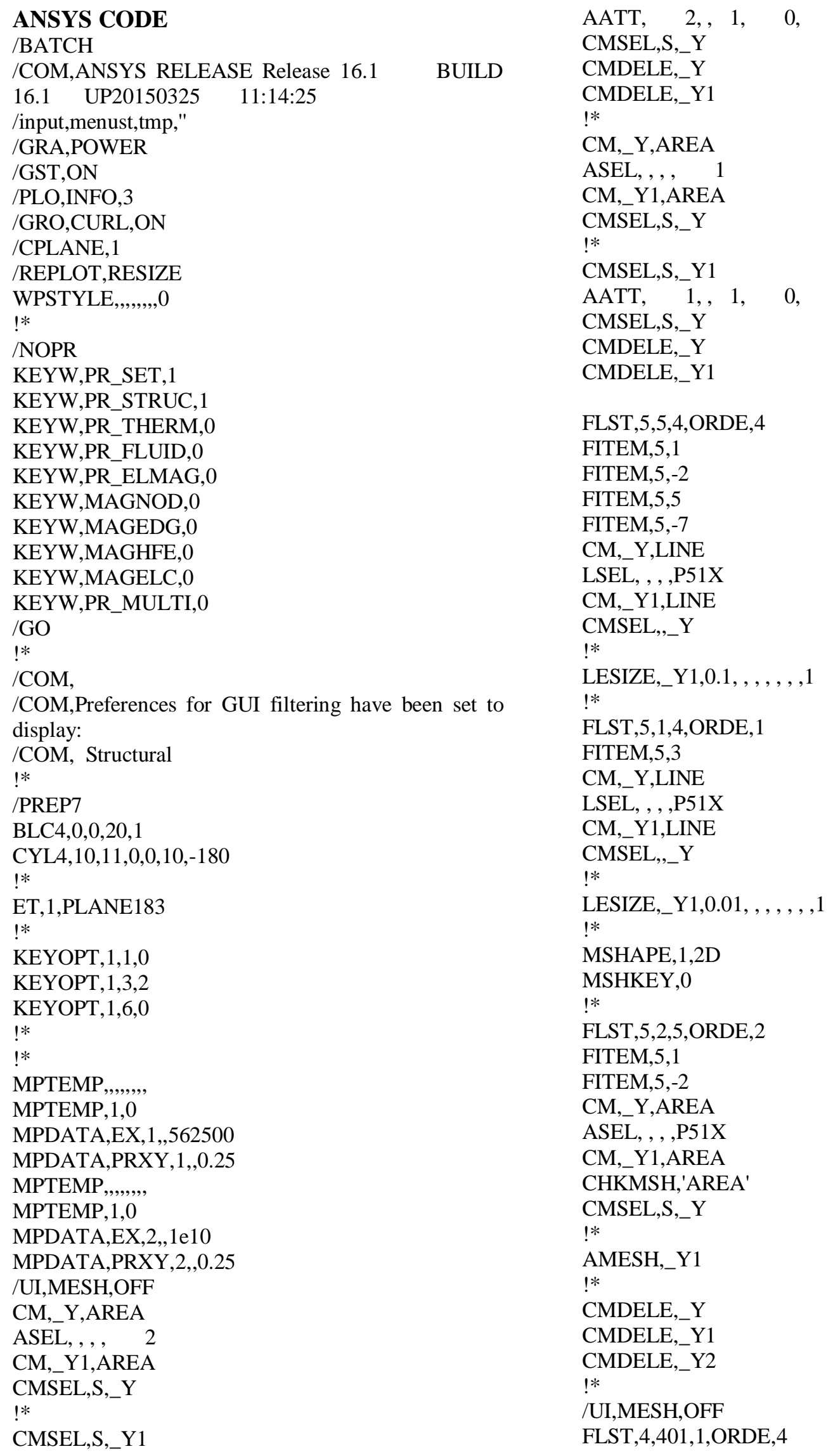


FITEM,4,90462

FITEM,4,-90463

FITEM,4,91093

FITEM,4,-91491

CP, 1,UY,P51X

!*

!*

/COM, CONTACT PAIR CREATION - START

CM,_NODECM,NODE

CM,_ELEMCM,ELEM

CM,_KPCM,KP

CM,_LINECM,LINE

CM,_AREACM,AREA

CM,_VOLUCM,VOLU

/GSAV,cwz,gsav,,temp

MP,MU,1,

MAT, 1

MP,EMIS, 1,7.88860905221e-031

$\mathrm{R}, 3$

REAL, 3

ET, 2,169

ET, 3,172

$\mathrm{R}, 3,,, 5.0,0.01,0$,

RMORE,,,1.0E20,0.0,1.0,

RMORE,0.0,0,1.0, 1.0,0.5

RMORE,0,1.0,1.0,0.0,,1.0

KEYOPT,3,3,0

KEYOPT,3,4,0

KEYOPT,3,5,3

KEYOPT,3,7,0

KEYOPT,3,8,0

KEYOPT,3,9, 1

KEYOPT,3,10,2

KEYOPT,3,11,0

KEYOPT,3,12,0

KEYOPT,3,2,0

! Generate the target surface

LSEL,S, , 5

CM,_TARGET,LINE

TYPE, 2

NSLL,S, 1

ESLN,S,0

ESURF

CMSEL,S,_ELEMCM

! Generate the contact surface

LSEL,S, ,, 3

CM,_CONTACT,LINE

TYPE, 3

NSLL,S, 1

ESLN,S,0

ESURF

ALLSEL

ESEL,ALL

ESEL,S,TYPE,,2

ESEL,A,TYPE,,3

ESEL,R,REAL,,3
/PSYMB,ESYS, 1

/PNUM,TYPE, 1

/NUM, 1

EPLOT

ESEL,ALL

ESEL,S,TYPE,,2

ESEL,A,TYPE,,3

ESEL,R,REAL,,3

CMSEL,A,_NODECM

CMDEL,_NODECM

CMSEL,A,_ELEMCM

CMDEL,_ELEMCM

CMSEL,S,_KPCM

CMDEL,_KPCM

CMSEL,S,_LINECM

CMDEL,_LINECM

CMSEL,S,_AREACM

CMDEL,_AREACM

CMSEL,S,_VOLUCM

CMDEL,_VOLUCM

/GRES,cwz,gsav

CMDEL,_TARGET

CMDEL,_CONTACT

/COM, CONTACT PAIR CREATION - END

/MREP,EPLOT

FINISH

/SOL

ANTYPE,0

NLGEOM, 1

NSUBST, 20,0,0

FLST, 2,6,4,ORDE, 4

FITEM,2,1

FITEM,2,-2

FITEM,2,4

FITEM,2,-7

!*

/GO

DL,P51X, ,UX,

FLST, 2, 1,4,ORDE, 1

FITEM,2,1

!*

/GO

DL,P51X, ,UY,

FLST, 2, 1, 1,ORDE, 1

FITEM,2,91292

!*

/GO

F,P51X,FY,-250

CMSEL,S,_Y

!*

AMESH,_Y1

!*

CMDELE,_Y

CMDELE,_Y1

CMDELE,_Y2

!* 